\title{
Progress in Nitrogen Removal in Bioelectrochemical Systems
}

\author{
Jin Sun, Hongrui Cao and Zejie Wang * \\ College of Environmental Science and Engineering, Qilu University of Technology (Shandong Academy \\ of Sciences), Jinan 250353, China; 1043119582@stu.qlu.edu.cn (J.S.); 1043119570@stu.qlu.edu.cn (H.C.) \\ * Correspondence: wangzejie@qlu.edu.cn; Tel.: +86-531-89631680
}

Received: 2 March 2020; Accepted: 20 June 2020; Published: 13 July 2020

\begin{abstract}
Nitrogenous compounds attract great attention because of their environmental impact and harmfulness to the health of human beings. Various biological technologies have been developed to reduce the environmental risks of nitrogenous pollutants. Bioelectrochemical systems (BESs) are considered to be a novel biological technology for removing nitrogenous contaminants by virtue of their advantages, such as low energy requirement and capacity for treating wastewaters with a low $\mathrm{C} / \mathrm{N}$ ratio. Therefore, increasing attention has been given to carry out biological processes related to nitrogen removal with the aid of cathodic biofilms in BESs. Prior studies have evaluated the feasibility of conventional biological processes including nitrification, denitrification, and anaerobic ammonia oxidation (anammox), separately or combined together, to remove nitrogenous compounds with the help of BESs. The present review summarizes the progress of developments in BESs in terms of the biological process, cathodic biofilm, and affecting factors for efficient nitrogen removal.
\end{abstract}

Keywords: nitrogen removal; bioelectrochemical systems; cathodic biofilm; reactor configuration; influencing factors

\section{Introduction}

Nitrogen, mainly in the forms of nitrate $\left(\mathrm{NO}_{3}{ }^{-}\right)$and ammonium $\left(\mathrm{NH}_{4}{ }^{+}\right)$, is considered to be an important element in water body, soil, and sediment matrix. Suitable nitrogen concentration favors the growth and metabolism of living beings, however, excessive input of nitrogen into the environment results in eutrophication, bringing severe impacts on the ecosystem and potential risks to human beings [1]. For example, excessive intake of nitrite can cause methemoglobinemia. Thus, increasing attention has been given to reduce the content of nitrogenous contaminants. Biological, chemical, and physicochemical methods have been evaluated as efficient ways to reduce the content of nitrogenous contaminants. Among the methods, the biological method is of particular interest due to its advantages of cost-effectiveness, less energy and chemical requirements, and satisfactory treatment efficiency [2]. Bioelectrochemical systems (BESs) are a novel biotechnology based on the extracellular electron transfer ability of exoelectrogens [3,4]. They are regarded as a potential biotechnology for reducing environmental pollution, along with the generation of green energies such as electric power and hydrogen gas, and value-added organic matters [5]. Exoelectrogens play irreplaceable roles in BESs [6]. They act as an electron sink in an anode surface to store electrons attracted by the degradation of organic matter, or as an electron source in a cathode surface to deliver electrons to reducible contaminants. Therefore, BESs could treat wastes with the aid of both anode and cathode reactions $[7,8]$. The emergence of biocathode is one breakthrough of BESs. In the biocathode, cathodic exoelectrogens receive electrons from the surface of the athode, and then transfer the electrons to reducible matters such as oxygen [9]. Considering that a positive potential difference exists between the anode and cathode in an electrochemical system when using acetate as an 
electron donor $\left(E_{0}{ }^{\prime}{ }_{\mathrm{HCO}} / \mathrm{CH} 3 \mathrm{COO}=-0.290 \mathrm{mV}\right.$ vs. standard hydrogen electrode $\left.(\mathrm{SHE})\right)$ and nitrate $\left(E_{0}{ }^{\prime} \mathrm{NO} / \mathrm{NO} 2=+433 \mathrm{mV}\right.$ vs. SHE$)$ or nitrite $\left(E_{0}{ }^{\prime} \mathrm{NO} / \mathrm{NO}=+350 \mathrm{mV}\right.$ vs. SHE$)$ as an electron acceptor, an energy-generating process is theoretically attainable [10]. The difference in redox potential of nitrate and $\mathrm{O}_{2}$ is less than $100 \mathrm{mV}, E_{0}{ }^{\prime}\left(\mathrm{O}_{2} / \mathrm{OH}^{-}\right)=0.40 \mathrm{~V}$ [11]. The reduction reaction of nitrate is summarized in Table 1 [12,13].

Table 1. Summary of denitrification reactions and theoretical potential [14-16].

\begin{tabular}{ccc}
\hline Process Cathodic & Reduction Reaction & $E_{0}$ (V vs. Ag/AgCl) \\
\hline Nitrate reduction & $\mathrm{NO}_{3}{ }^{-}+2 \mathrm{e}^{-}+2 \mathrm{H}^{+} \rightarrow \mathrm{NO}_{2}{ }^{-}+\mathrm{H}_{2} \mathrm{O}$ & +0.233 \\
Nitrite reduction & $\mathrm{NO}_{2}{ }^{-}+\mathrm{e}^{-}+2 \mathrm{H}^{+} \rightarrow \mathrm{NO}+\mathrm{H}_{2} \mathrm{O}$ & +0.150 \\
Nitric oxide reduction & $\mathrm{NO}+\mathrm{e}^{-}+\mathrm{H}^{+} \rightarrow 0.5 \mathrm{~N}_{2} \mathrm{O}+0.5 \mathrm{H}_{2} \mathrm{O}$ & +0.975 \\
Nitrous oxide reduction & $0.5 \mathrm{~N}_{2} \mathrm{O}+\mathrm{e}^{-}+\mathrm{H}^{+} \rightarrow 0.5 \mathrm{~N}_{2}+0.5 \mathrm{H}_{2} \mathrm{O}$ & +1.155 \\
Overall denitrification & $\mathrm{NO}_{3}{ }^{-}+6 \mathrm{H}^{+}+5 \mathrm{e}^{-} \rightarrow 0.5 \mathrm{~N}_{2}+3 \mathrm{H}_{2} \mathrm{O}$ & +0.549 \\
\hline
\end{tabular}

The removal process of ammonia in BES can be illustrated as follows [17]:

Anode:

$$
\mathrm{CH}_{3} \mathrm{COO}^{-}+2 \mathrm{H}_{2} \mathrm{O} \rightarrow 2 \mathrm{CO}_{2}+7 \mathrm{H}^{+}+8 \mathrm{e}^{-}
$$

Cathode:

$$
\begin{aligned}
& \mathrm{NH}_{4}^{+}+1.5 \mathrm{O}_{2} \rightarrow \mathrm{NO}_{2}^{-}+\mathrm{H}_{2} \mathrm{O}+2 \mathrm{H}^{+} \\
& \mathrm{NO}_{2}^{-}+3 \mathrm{e}^{-}+4 \mathrm{H}^{+} \rightarrow 0.5 \mathrm{~N}_{2}+2 \mathrm{H}_{2} \mathrm{O}
\end{aligned}
$$

Nitrate has also been reduced with the aid of electroactive denitrifying bacteria within the cathodic biofilm [13]. It was observed that a complete denitrification process occurred in biocathode BESs, resulting in $0.66 \pm 0.01 \mathrm{~kg} \mathrm{~N} \mathrm{~m}^{-3} \mathrm{~d}^{-1}$ at a $\mathrm{C} / \mathrm{N}$ ratio of $3.5 \pm 0.3$ and the highest electric power density of $0.84 \pm 0.05 \mathrm{~W} \mathrm{~m}^{-2}$. Afterwards, it was revealed that BESs have the ability to treat wastewaters with a low $\mathrm{C} / \mathrm{N}$ ratio because the electrons for reducing nitrate have been provided by the cathode instead of organic matters in the conventional bioprocess [18]. Recently, increasing attention has been given to evaluate nitrogen removal with the assistance of BESs in terms of influencing factors, reactor configuration, and microbiology.

Considering the significance of nitrogen removal and increasing concerns, the present review summarizes the development of nitrogen reduction within the cathodic biofilm of BESs. The typical configuration of BESs and the principle of biological nitrogen reduction are narrated for newcomers focusing on BESs and nitrogen removal. Moreover, the development of a reactor configuration for the purpose of nitrogen reduction, the influencing factors and strategies to promote nitrogen removal efficiency, and biocathodic microbiology are discussed. The present review expects to provide valuable information on the current development of nitrogen removal by BESs, and to discuss the challenges for future investigations and development of more efficient removal of nitrogen contaminants with the aid of BESs.

\section{Nitrogen Removal Process in BESs}

A biological process is generally used to remove nitrogen from wastewater. The traditional process is nitrification and denitrification (Figure 1, Table 1). There are also some new denitrification technologies for nitrogen in wastewater, such as simultaneous nitrification-denitrification (SND), shortcut SND, and anaerobic ammonia oxidation (anammox) [19]. These can be combined with the traditional nitrogen removal process to increase its advantages or achieve better treatment results, and to reduce the treatment cost. Compared with heterotrophic denitrification in traditional (BNR), BES technology can avoid the need for exogenous organic carbon sources by generating electric power from the treatment of nitrogenous compounds in wastewater, which can substantially reduce the total cost and achieve sustainable wastewater treatment $[20,21]$. However, most nitrogen that exists in wastewater is in the form of ammonium, and therefore nitrification is needed in a BES by adding 
a separate aerobic nitrifying unit before the denitrification or increasing aeration in the cathode to oxidize ammonium to nitrate $[10,22]$.

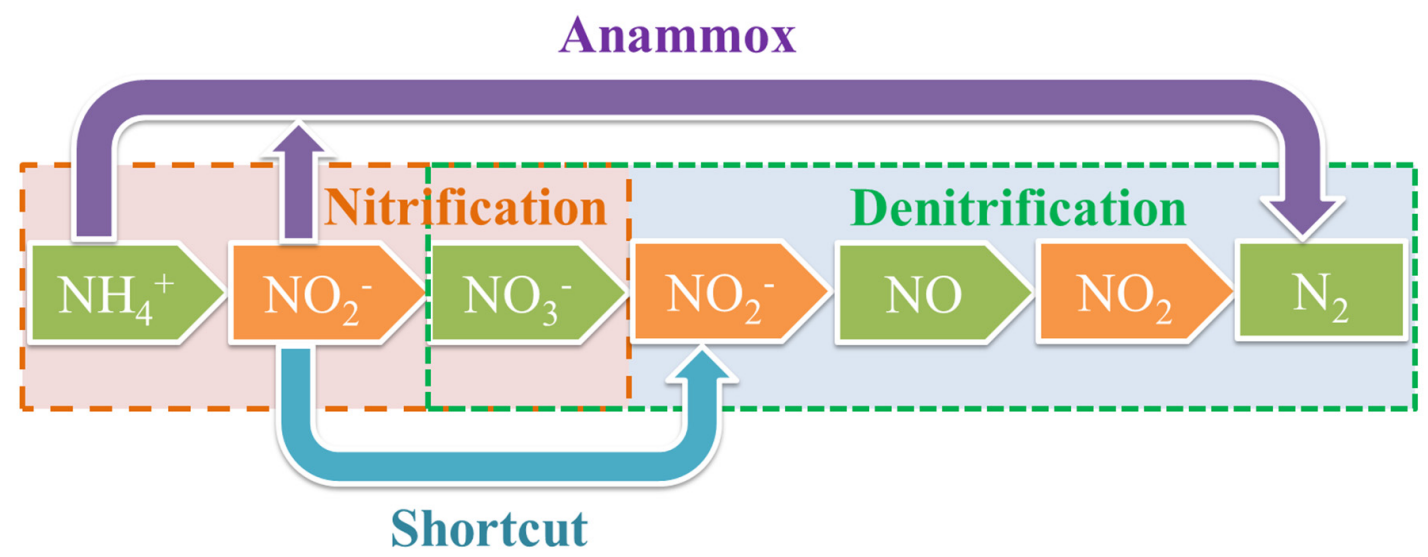

Figure 1. Flow chart of the traditional biological process for removal of nitrogenous compounds.

\subsection{Denitrification Process}

Autotrophic denitrification plays an important role in BESs. Autotrophic denitrification bacteria utilize hydrogen, iron, or sulfur chemical compounds as energy sources and carbon dioxide or bicarbonate as the carbon source. The biotic process involving ferrous ions $\left(\mathrm{Fe}^{2+}\right)$ decreases nitrate to nitrite autotrophically in low-iron surroundings [23]. The standard potential of $\mathrm{NO}_{3}{ }^{-}$is high enough to act theoretically as electron acceptors in BESs. However, prior research has demonstrated that the $\mathrm{NO}_{3}{ }^{-}$ reduction reaction does not occur on the surface of an abiotic cathode; and later, it has been observed that the denitrification process was successfully achieved within the cathodic biofilm [13,24,25]. For conventional denitrification, heterotrophic denitrifying bacteria require organic matter as electron donors. However, wastewaters with low $\mathrm{C} / \mathrm{N}$ ratio are difficult to treat through a conventional denitrification process. Insufficient organic carbon leads to partial denitrification and production of toxic intermediate such as $\mathrm{NO}_{2}{ }^{-}$or greenhouse gas of $\mathrm{N}_{2} \mathrm{O}$. For BESs, however, the cathode acts as a solid electron donor, and autotrophic denitrifiers carry out the nitrogen removal process, along with heterotrophic denitrifiers that work with organic matter as an electron donor. Therefore, BESs could successfully polish wastewaters with a low $\mathrm{C} / \mathrm{N}$ ratio such as groundwater [26]. Zhao et al. observed that over $97 \%$ of $\mathrm{NO}_{3}{ }^{-}$was removed from groundwater with a $\mathrm{C} / \mathrm{N}$ ratio as low as 0.75 , and no accumulation of $\mathrm{NO}_{2}^{-}$was confirmed [27]. The denitrification process was carried out by both heterotrophic and autotrophic denitrifiers. It was revealed that heterotrophic denitrifiers dominated in the suspension, whereas autotrophic denitrifiers were located predominantly within the biofilm, because autotrophic denitrifiers took advantage of the cathode as an electron donor and competed over the heterotrophic denitrifiers within the biofilm. Relative to conventional denitrification, BES technology can reduce the operational cost because of the avoidance of the additional supplementation of organic carbon when treating wastewaters with a low $\mathrm{C} / \mathrm{N}$ ratio [28].

Ding et al. found that a BES combined with the flocculation process achieved an ammonia removal rate of $269.2 \pm 0.5 \mathrm{~g} \mathrm{~m}^{-3} \mathrm{~d}^{-1}$ (removal efficiency of $99.1 \pm 0.1 \%$ ), a maximum power density of $37.5 \mathrm{~W}^{\prime} \mathrm{m}^{-3}$, and a CE (Coulomb efficiency) of $21.6 \%$ in the treatment of swine wastewater. The net economic gain was evaluated to be $\$ 0.026 \mathrm{~m}^{-3}$ [29]. Table 2 summarizes some traditional nitrogen removal processes and nitrogen removal by BESs. 
Table 2. Removal of nitrogenous contaminant via different processes.

\begin{tabular}{|c|c|c|c|c|c|c|c|}
\hline Reactor Type & Wastewater & Removal Process & $\begin{array}{l}\text { Concentration Rate } \\
\left(\mathrm{mg} / \mathrm{L} \mathrm{NH}_{4}{ }^{+}-\mathrm{N}\right)\end{array}$ & HRT/Voltage & Volume & Removal Efficiency & Ref. \\
\hline Traditional process & Synthetic petrochemical wastewater & SND & 127 & $24 \mathrm{~h}$ & $4 \mathrm{~L}$ & $87.81 \%$ & [30] \\
\hline Traditional process & Domestic sewage & Shortcut SND & $\mathrm{TN}=84.9 \mathrm{mg} \mathrm{L}^{-1}$ & $9 \mathrm{~h}$ & $300 \mathrm{~L}$ & $63.2 \%$ & [31] \\
\hline Traditional process & Sewage taken from the primary clarifier & $\begin{array}{l}\text { Anammox Partial } \\
\text { Denitrification }\end{array}$ & $\mathrm{TN}=46 \mathrm{mg} \mathrm{L}^{-1}$ & $4.6 \mathrm{~h}$ & $28 \mathrm{~L}$ & $88.38 \%$ & [32] \\
\hline Traditional process & Synthetic & $\begin{array}{l}\text { Denitrification } \\
\text { Anammox }\end{array}$ & $\mathrm{TN}=227.60 \mathrm{mg} \mathrm{L}^{-1}$ & $0.2 \mathrm{~h}$ & $1 \mathrm{~L}$ & $94.68 \%$ & [33] \\
\hline Single-chamber MFC (microbial fuel cell) & Synthetic & SND & $11 \mathrm{~V}=22.004 \mathrm{~mL}$ & $35 \mathrm{~h}$ & $28 \mathrm{~mL}$ & $\begin{array}{l}74.0010 \\
96.8 \%\end{array}$ & [34] \\
\hline $\begin{array}{l}\text { Single-chamber MFC } \\
\text { SFe }\end{array}$ & Raw coking wastewater & Denitrification & $\mathrm{TN}=350.4 \pm 7.9 \mathrm{mg} \mathrm{L}^{-1}$ & $125 \mathrm{~h}$ & $0.5 \mathrm{~L}$ & $97.9 \pm 2.1 \%$ & [35] \\
\hline Single-chamber MFC & $\begin{array}{l}\text { Synthetic } \\
\text { Sylet }\end{array}$ & SND & $1 \mathrm{~N}-300.430$ & $12 \mathrm{~h}$ & $1.2 \mathrm{~L}$ & $100 \%$ & [36] \\
\hline Single-chamber MFC & Synthetic & SND & 130 & - & $0.1 \mathrm{~L}$ & $98 \%$ & [17] \\
\hline Dual-chamber MFC & Synthetic & SND & 53.3 & $6.86 \mathrm{~h}$ & $0.4 \mathrm{~L}$ & $94.1 \%$ & [22] \\
\hline Dual-chamber MFC & Coke oven & Ammonia removal & 740 & $\begin{array}{c}.000 \mathrm{ht} \\
68 \mathrm{~h}\end{array}$ & $1 \mathrm{~L}$ & $40 \%$ & [37] \\
\hline Dual-chamber pMFC & Kitchen waste effluent & Ammonia removal & $1550 \pm 20$ & - & $1.85 \mathrm{~L}$ & $44.1-59.8 \%$ & {$[38]$} \\
\hline Dual-chamber MEC & Synthetic & Denitrification & $\mathrm{NO}_{3}{ }^{-}-\mathrm{N}=1500 \mathrm{mg} \mathrm{L}^{-1}$ & $96 \mathrm{~h}$ & $0.15 \mathrm{~L}$ & $0.25 \mathrm{~kg} \mathrm{~N} \mathrm{~m}^{-3} \mathrm{~d}^{-1}$ & [39] \\
\hline Dual-chamber MEC & Synthetic & Denitrification & $\mathrm{NO}^{-}{ }^{-} \mathrm{N}=100 \mathrm{mg} \mathrm{L}^{-1}$ & $32.4 \mathrm{~h} ; 0.70 \mathrm{~V}$ & $0.675 \mathrm{~L}$ & $98.3 \%$ & [26] \\
\hline Dual-chamber MEC & Synthetic & Denitrification & $\mathrm{NO}_{3}{ }^{-}-\mathrm{N}=50 \mathrm{mg} \mathrm{L}^{-1}$ & $8 \mathrm{~h} ; \mathrm{I}=40 \mathrm{~m} \mathrm{~A}$ & $12 \mathrm{~L}$ & $97 \%$ & [27] \\
\hline Dual-chamber MFC & Synthetic & Nitrification & 26.9 & $0.26 \mathrm{~kg} \mathrm{~N} \mathrm{~m}^{-3} \mathrm{~d}^{-1}$ & $0.2 \mathrm{~L}$ & $96.4 \%$ & {$[40]$} \\
\hline Dual-chamber MEC & Synthetic & Nitritation-anammox & 500 & $60 \mathrm{~h} ; 0.80 \mathrm{~V}$ & $1.49 \mathrm{~L}$ & $97.6 \pm 5.4 \%$ & [41] \\
\hline Dual-chamber MFC & Municipal sewage & Denitrification & $\mathrm{NO}_{3}{ }^{-}-\mathrm{N}=49.33 \mathrm{mg} \mathrm{L}^{-1}$ & - & $2.08 \mathrm{~L}$ & $125.7 \pm 6 \mathrm{~g} \mathrm{NO}_{3}-\mathrm{N} \mathrm{m}^{-3} \mathrm{~d}^{-1}$ & [42] \\
\hline Three-chamber MFC & Municipal wastewater & SND & $45.73 \pm 2.46$ & $24 \mathrm{~h}$ & $0.4 \mathrm{~L}$ & $91.76 \pm 3.32 \%$ & [43] \\
\hline
\end{tabular}




\subsection{Simultaneous Nitrification-Denitrification Process}

Ammonium contributes a significant fraction of the total nitrogen concentration. It can be removed through a simultaneous nitrification-denitrification (SND) process, in which $\mathrm{NH}_{4}{ }^{+}$is firstly transformed to $\mathrm{NO}_{3}{ }^{-}$by nitrifiers, and then reduced to $\mathrm{N}_{2}$ through the following denitrification process. Nitrification is an aerobic process, and thus oxygen is a crucial factor in the conversion of $\mathrm{NH}_{4}{ }^{+}$to $\mathrm{NO}_{3}{ }^{-}$. Moreover, an oxygen gradient within biofilms has resulted in biofilm stratification in which nitrifiers occupied the outer layer, whereas denitrifiers dominated the inner layer [44], and then SND could be achieved within one biofilm, leading to the removal of $\mathrm{NH}_{4}{ }^{+}$as $\mathrm{N}_{2}$ in BESs.

Various kinds of reactor configurations with different aeration manners have been adopted to realize the SND process in BESs. Virdis et al. achieved the SND process for the first time in a two-chamber microbial fuel cell (MFC) in which the cathodic influent was externally aerated to supply sufficient dissolved oxygen (DO) for the nitrification process [22] (Figure 2A). The research resulted in up to $94.1 \pm 0.9 \%$ nitrogen removal, with an effluent concentration of nitrate and ammonium as low as $1.0 \pm 0.5 \mathrm{mg} \mathrm{N} \mathrm{L}^{-1}$ and $2.13 \pm 0.05 \mathrm{mg} \mathrm{N} \mathrm{L}^{-1}$, respectively (Table 3). For the system, however, circulating pumps were needed to pump the aerated wastewater into the cathodic compartment, which consumed additional electrical energy and increased the operational costs of the systems [44]. With an internal aeration diffuser, the SND occurred within the cathodic biofilm attaching on the surface of a membrane filtration cathode made of carbon felt [45] (Figure 2B). The $\mathrm{NH}_{4}{ }^{+}$concentration was reduced as low as $0.76 \pm 1.01 \mathrm{mg} \mathrm{N} \mathrm{L}^{-1}$ in the effluent, with an initial concentration of $52.39 \pm 3.85 \mathrm{mg} \mathrm{N} \mathrm{L}^{-1}$. However, only $23.3 \pm 6.5 \%\left(8.15 \pm 2.00 \mathrm{mg} \mathrm{N} \mathrm{L}^{-1}\right)$ of $\mathrm{NO}_{3}{ }^{-}$was removed from the cathodic solution, implying that the denitrification efficiency was quite low in the designed system because of insufficient electrons donated by the anodic biofilm for complete denitrification [45]. Wu et al. found that using an electroconductivity aerated membrane as the biocathode substrate was a more efficient way to promote the utilization efficiency of DO through controlling the aeration intensity [46] (Figure 2C). The designed MFC system achieved the highest $\mathrm{NH}_{4}{ }^{+}$removal efficiency of $80.90 \%\left(0.16 \mathrm{~kg} \mathrm{~N} \mathrm{~m}^{-3}\right.$ net cathode chamber $\mathrm{d}^{-1}$ ) from wastewater with a $\mathrm{C} / \mathrm{N}$ ratio of 2.8 , and the concentration of $\mathrm{NO}_{3}{ }^{-}$ and $\mathrm{NO}_{2}{ }^{-}$in the effluent was reduced to as low as 0.12 and $2.18 \mathrm{mg} / \mathrm{L}$, respectively. The maximum power density of $4.20 \pm 0.12 \mathrm{~W}^{\prime} \mathrm{m}^{-3}$ was obtained at a current density of $4.10 \pm 0.11 \mathrm{~A} \mathrm{~m}^{-2}$ (external resistance $=10 \mathrm{X}$ ). Recently, a membrane bioelectrochemical reactor was constructed by integrating an MFC into an aerobic membrane bioreactor [47] (Figure 2D). It alleviated the biofouling because of the improved sludge properties in terms of the reduced extracellular polymeric substance and mixed liquor volatile suspended solids, achieving the highest nitrogen removal efficiency of $84.3 \%$.

Table 3. Efficiency of nitrogen removal via different process in Bioelectrochemical systems (BESs).

\begin{tabular}{|c|c|c|c|c|c|}
\hline Reactor Type & Removal Process & Wastewater & $\begin{array}{c}\text { Concentration Rate } \\
(\mathrm{mg} / \mathrm{L} \mathrm{NH} \\
4\end{array}$ & Removal Efficiency & Ref. \\
\hline Dual-chamber MFC & SND & Synthetic & 407 & $94.1 \pm 0.9 \%$ & [22] \\
\hline Three-chamber MFC & Shortcut SND & Municipal & 50 & $99.9 \%$ & [48] \\
\hline Membrane-aerated BES & $\begin{array}{l}\text { Membrane-aerated } \\
\text { nitritation-anammox }\end{array}$ & Synthetic & $500 \pm 10$ & $94.8 \pm 7.7 \%$ & [41] \\
\hline $\begin{array}{l}\text { The sulfide removal } \\
\text { and nitrification MFC }\end{array}$ & Nitrification & Synthetic & $26.8 \pm 0.3$ & $96.4 \%$ & [40] \\
\hline
\end{tabular}

BESs with passive aeration can supply sufficiently dissolved oxygen to make sure the complete SND process has a low concentration of harmful intermediates such as $\mathrm{NO}_{2}{ }^{-}$and $\mathrm{N}_{2} \mathrm{O}$. However, the aeration process consumes electrical energy, leading to a less positive energy budget. An air-breathing cathode takes advantage of an air permeable cathode substrate to achieve oxygen diffusion to the oxygen reduction catalyst layer, reducing the energy requirement for aeration and increasing the electric current generation [49]. Yan et al. achieved the SND process in air-breathing single chambers through pre-enriching nitrifying biofilm on the surface of the air cathode [34] (Figure 2E). With diethylamine-functionalized polymer as the Pt catalyst binder, the designed reactor removed up to $96.8 \%$ of ammonia and a maximum power density of $900 \pm 25 \mathrm{~mW} \mathrm{~m}^{-2}$ as compared with $90.7 \%$ 
and $945 \pm 42 \mathrm{~mW} \mathrm{~m}^{-2}$ with a Nafion binder. Without pre-enrichment, a nafion binder cathode could also remove ammonia, but the efficiency was reduced to $54.5 \%$. The maximum total nitrogen removal efficiency reached $93.9 \%$ for MFCs with the diethylamine-functionalized polymer (DEA) binder.
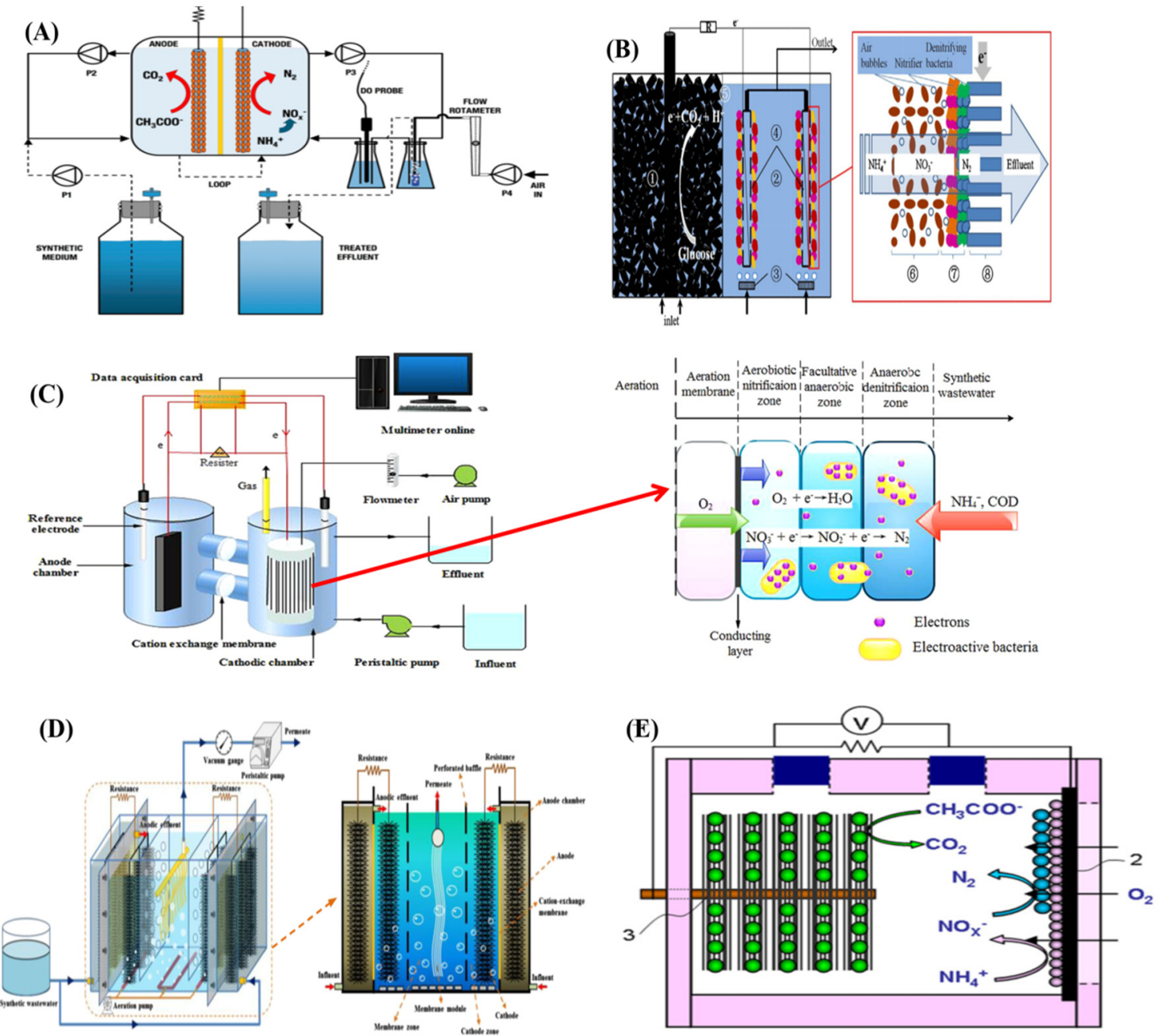

Figure 2. (A) Schematic representation of the experimental setup, dual-chamber microbial fuel cell (MFC) for simultaneous nitrification and denitrification [22]; (B) Schematic of the integrated system, and ammonium evolution in the cathode chamber. The reactor was equally divided into two chambers (an anodic anaerobic zone and a cathodic aerobic zone) by a Plexiglas baffle, biocathodes for simultaneous nitrification and denitrification [45]; (C) Schematic diagram of the EMA-MFC system, and nitrogen removal in the cathodic chamber [46]; (D) Schematic diagram of the MBER [47], and (E) single-chamber air-cathode MFCs for simultaneous nitrification and denitrification [34]. Reproduced with copyright, Elsevier and Springer Nature.

Yang et al. observed an upflow bioelectrochemical filter reactor (UBEF) which was designed without positive aeration in-priority for treating real domestic wastewater. Moreover, since it was aeration free, the operation cost per day of the UBEF was also decreased by $18.70 \%$. This SND reactor was mainly composed of a reaction tank, aeration pump, automatic controller, airflow meter, and air distributor, and the capital cost of these items was USD 69.2. On the basis of its pollutant removal abilities of $1.5 \mathrm{~kg} \mathrm{COD} \mathrm{m}^{-3} \mathrm{~d}^{-1}$ and $0.32 \mathrm{~kg} \mathrm{NH}_{4}{ }^{+}-\mathrm{N} \mathrm{m}^{-3} \mathrm{~d}^{-1}$, the capital cost per ton of this SND reactor could reach USD 46.6 (COD) and USD 216.2 (nitrogen). Consequently, it can be easily concluded that the UBEF spent less, i.e., $33.69 \%$ of the capital cost per ton (COD) and $60.71 \%$ (nitrogen) as compared with the SND sludge process. 


\subsection{Shortcut SND Process}

The shortcut SND process controls the nitrification process of ammonia in the nitrite stage, followed by denitrification, that is, the nitrogen removal process is $\mathrm{NH}_{4}{ }^{+} \rightarrow \mathrm{NO}_{2}{ }^{-} \rightarrow \mathrm{N}_{2}$. SND can reduce the amount of aeration and the addition of carbon sources. Thus, the cost of shortcut SND could be significantly reduced relative to the SND process.

The shortcut SND process has been considered to be a technically feasible and economically favorable biological process for treatment, especially for those with high ammonium concentration or low nitrogen contained wastewater $\mathrm{C} / \mathrm{N}$ ratio [50]. It has been successfully integrated into BESs because nitrate and nitrite could be interchangeably used as electron acceptors [51-53]. It has been revealed that nitrite could be reduced either electrochemically or biologically in the presence of oxygen [51]. A similar phenomenon was observed by Li et al. [54], who suggested abolishing oxygen or inhibiting nitrite-oxidizing bacteria (NOB) to favor nitrogen removal. With the addition of $\mathrm{NaN}_{3}$, for example, the total nitrogen removal was increased by $50 \%$ to the highest removal rate of $0.075 \pm 0.008 \mathrm{~kg} \mathrm{~m}^{-3}$ net cathode chamber $\mathrm{d}^{-1}$. However, a recent research revealed that the addition of $\mathrm{NaN}_{3}$ decreased the nitrate production, while it increased the $\mathrm{N}_{2} \mathrm{O}$ yield by 5.6, demonstrating the addition of an inhibitor limited the NOB activity and also, to a certain extent, the reduction of nitrite [53]. A previous research demonstrated that low dissolved oxygen concentration favored the growth of ammonia-oxidizing bacteria (AOB) relative to NOB and was beneficial for the accumulation of nitrite [19]. Therefore, limited dissolved oxygen promoted the bioelectrochemical conversion of $\mathrm{NH}_{4}{ }^{+}$via the accumulation of nitrite instead of nitrate.

The shortcut SND process was generally carried out within a stratified cathodic biofilm. Recently, Li et al. developed a three-chamber MFC with two independent cathode chambers sharing one anode chamber to carry out the shortcut SND process [48] (Figure 3). For the reactor, one cathode chamber was aerated to supply oxygen for shortcut nitrification to accumulate $\mathrm{NO}_{2}{ }^{-}$from the conversion of $\mathrm{NH}_{4}{ }^{+}$, in which most of the $\mathrm{NH}_{4}{ }^{+}$was transformed to $\mathrm{NO}_{2}{ }^{-}$, with a $\mathrm{NO}_{2}{ }^{-} / \mathrm{NO}_{3}{ }^{-}$ratio of three. Then, the $\mathrm{NO}_{2}{ }^{-}$enriched effluent was recirculated into another cathode chamber, where autotrophic denitrification occurred and $\mathrm{NO}_{2}^{-}$was reduced to $\mathrm{N}_{2}$. It was found that the nitrification operation time decreased with an increased DO concentration in the range of 1-3.5 $\mathrm{mg} \mathrm{L}^{-1}$, because the higher DO concentration stimulated the growth of AOB and accelerated the conversion of $\mathrm{NH}_{4}{ }^{+}$. The total nitrogen removal efficiency achieved was as high as $99.9 \%$, with a removal rate of $0.0125 \mathrm{~kg} \mathrm{~N} \mathrm{~m}^{-3} \mathrm{~d}^{-1}$ at a DO concentration of $3.5 \mathrm{mg} \mathrm{L}^{-1}$ (Table 3). Compared with conventional dual-chamber reactors, the three-chamber system separated the nitrification and denitrification process into two independent cathodic biofilms, therefore, making it easy to operate and it was beneficial for the stable operation due to the minimized impact of $\mathrm{pH}$.

\subsection{Anaerobic Ammonia Oxidation (Anammox) Integrated Process}

In an MFC, organic substrates are oxidized by exoelectrogenic bacteria, which produce electrons that are transferred to an anode electrode, and then flow to a cathode. The anode and cathode are linked by a conductive material containing a resistor. Protons produced at the anode, migrate through the solution across a cation exchange membrane to the cathode chamber where they combine with a reducible compound and electrons. Bioelectrochemical denitrification is carried out by autotrophically denitrifying bacteria that are capable of accepting electrons from a solid electron donor (e.g., a cathode electrode) [55]. 


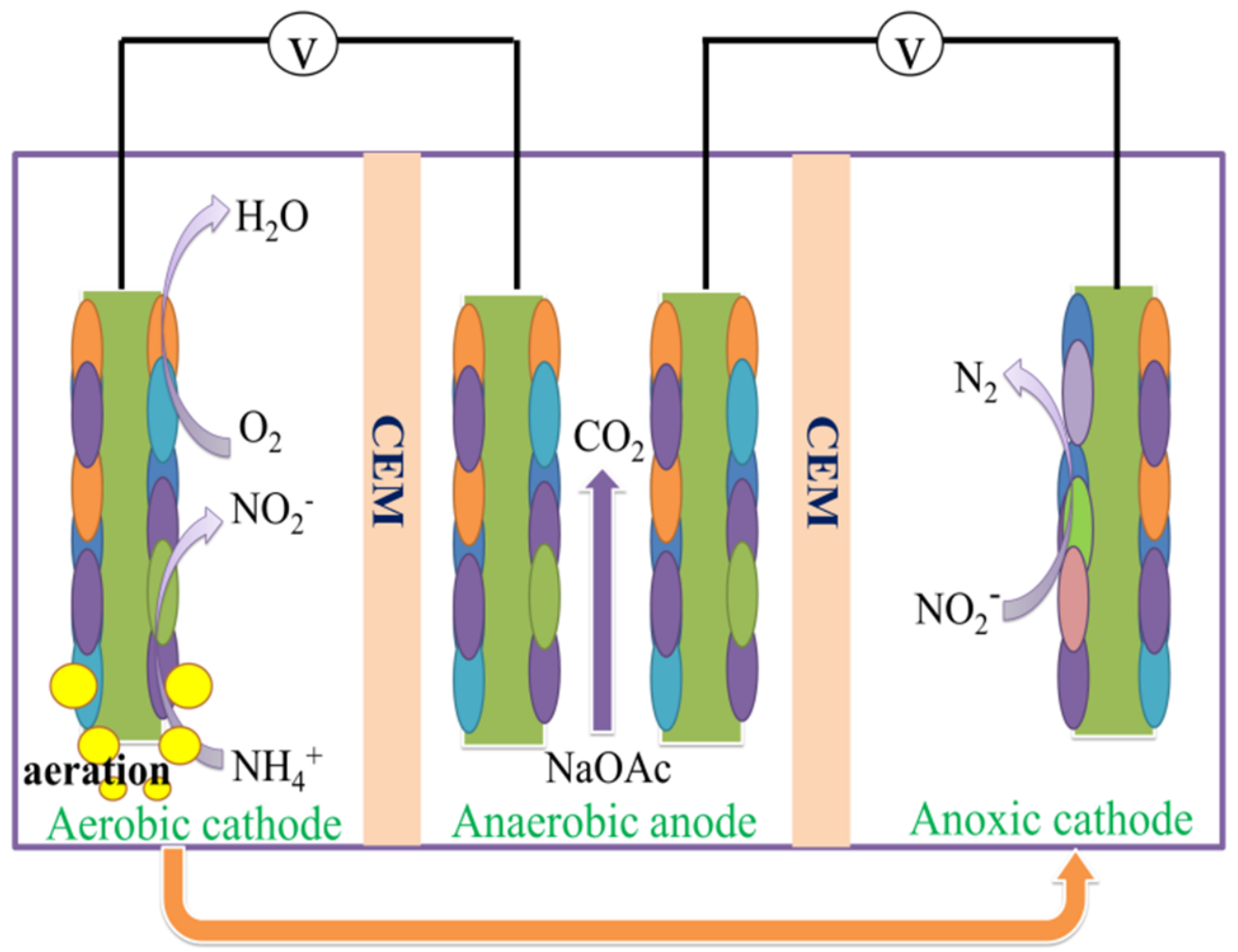

\section{Shortcut nitrification MFC}

Figure 3. Schematic of the three-chamber MFC to carry out the shortcut nitrification and denitrification process for nitrogen removal. Modified from [48].

$\mathrm{NH}_{4}{ }^{+}$can be removed through both nitrification and anammox processes. Anammox is considered to be a more energy effective process relative to conventional nitrification because of the lower oxygen requirement, lower energy consumption, lower sludge yield, and no need of adding external organic [33,56-58].

$$
\begin{gathered}
\mathrm{NH}_{4}{ }^{+}+1.5 \mathrm{O}_{2} \rightarrow \mathrm{NO}_{2}^{-}+\mathrm{H}_{2} \mathrm{O}+2 \mathrm{H}^{+} \\
\mathrm{NH}_{4}{ }^{+}+\mathrm{NO}_{2}{ }^{-} \rightarrow \mathrm{N}_{2}+\mathrm{H}_{2} \mathrm{O}
\end{gathered}
$$

However, an inevitable problem of anammox is the increased concentration of $\mathrm{NO}_{3}{ }^{-}$as a byproduct. As a result, the denitrification process has usually been integrated into the anammox system to denitrify the accumulated $\mathrm{NO}_{3}{ }^{-}$. Integrating anammox with denitrification, $\mathrm{NH}_{4}{ }^{+}$was successfully removed with no accumulation of $\mathrm{NO}_{3}{ }^{-}$, verifying that coupling anammox and denitrification in MFCs was effectively operated [59]. It was observed that sludge was responsible for the anammox process, whereas the biofilm carried out the denitrification process. This could be due to the fact that the cathode, as an electron donor, could promote the growth of denitrifiers within the biofilm, while suppressing the metabolism of anammox bacteria. Moreover, the anammox and denitrification process has been observed in a wetland MFC system because of the significantly enriched denitrifiers and anammox bacteria in the bottom layer of the central aerated MFC reactor [60]. $\mathrm{NH}_{4}{ }^{+}-\mathrm{N}$ removal efficiency reached as high as $92 \%$, along with a total nitrogen (TN) removal efficiency of $69 \%$.

Anammox along with the nitritation process has been realized in a membrane-aerated BES equipped with a gas-permeable silicone membrane module to enhance nitrogen removal [41]. The cathodic biofilm was stratified into aerobic and anoxic areas to carry out the nitritation, anammox, and denitrification processes, respectively. It was observed that the hydraulic retention time (HRT) was a crucial factor for both contaminant removal and energy production. With an increased HRT from 20 to $90 \mathrm{~h}$, the $\mathrm{C} / \mathrm{N}$ ratio decreased from 1.1 to 0.5 , and the $\mathrm{DO}$ concentration increased from 
0.2 to $1.2 \mathrm{mg} / \mathrm{L}$. Therefore, the activity of anammox bacteria, denitrifiers, and exoelectrogens were consequently affected. At an HRT of $60 \mathrm{~h}$, the removal efficiency of $\mathrm{NH}_{4}{ }^{+}$achieved was as high as $94.8 \pm 7.7 \%$ (Table 3). Increasing the HRT from 20 to $90 \mathrm{~h}$, resulted in an increase in dissolved oxygen content and a decrease in the activity of denitrifying bacteria. Oxygen took the place of nitrate as an electron acceptor and competed with the AOB.

Zhang et al. found that anammox sludge could be used as an anode microbial catalyst to promote the efficiency of anammox removal of total nitrogen (TN). The operation of the system with a nitrogen loading rate (NLR) of $1.74 \mathrm{~kg} \mathrm{~N} \mathrm{~m}^{-3} \mathrm{~d}^{-1}$ showed a TN removal rate of $96.3 \%$, and the highest nitrogen removal rate (NRR, $1.69 \mathrm{~kg} \mathrm{~N} \mathrm{~m}^{-3} \mathrm{~d}^{-1}$ ) was obtained. Compared with the open circuit (control group), it was increased by $14.9 \%$ and $0.30 \mathrm{~kg} \mathrm{~N} \mathrm{~m}^{-3} \mathrm{~d}^{-1}$, respectively. The maximum voltage $(39.8 \mathrm{mV})$ and power density $\left(21.20 \pm 0.05 \mathrm{~mW} \mathrm{~m}^{-3}\right.$, standardized to anode surface area) were also observed [61].

\subsection{High-Strength Nitrogenous Wastewaters}

The nitrogen removal process can treat high-nitrogen wastewater. It has a large application in industry, because high-nitrogen wastewater exists in many industries, such as swine wastewater, soybean protein wastewater, and chemical wastewater.

In electrochemistry, some studies have evaluated the microbial electrolytic cell (MEC) process to treat synthetic wastewater with high ammonia nitrogen, such as pig wastewater. Lim et al. found that the average total nitrogen removal efficiencies for the applied voltages of 0,1 , and $2 \mathrm{~V}$ were $39.8 \%, 49.5 \%$, and $58.7 \%$, respectively, when the initial nitrogen concentration was $1992.7 \pm 86.2 \mathrm{mg} \mathrm{L}^{-1}$ [62]. Sevda et al. achieved an ammonia removal efficiency of $40 \%$ and a stable power density of $112.50 \mathrm{~mW} \mathrm{~m}^{-3}$ at the HRT of $68 \mathrm{~h}$ from the treatment of wastewater with an ammonia loading rate of $0.43 \mathrm{~kg} \mathrm{NH}_{3}^{-} \mathrm{m}^{-3}$ $\mathrm{d}^{-1}$ [37]. The results demonstrated that a BES could also achieve high removal efficiency of nitrogen from high-strength nitrogenous wastewaters.

\subsection{Alternatives to Organic Electron Donors}

For conventional BESs, organic carbon has been decomposed in the anode side to supply electrons for the cathodic nitrogen removal. The organic carbon was altered to inorganic matters as an electron donor. Du et al. replaced the bioanode with a photocatalytic anode comprised of $\mathrm{TiO}_{2}$ nanotube on titanium substrate and evaluated the feasibility of biocathodic oxygen reduction and nitrification [63] (Figure 4A). It was shown that the BES removed $34 \% \mathrm{NH}_{4}^{+}$at an initial concentration of $78 \mathrm{mg} \mathrm{L}^{-1}$ within $4 \mathrm{~h}$. Sulfide was also used as an electron donor, replacing organic carbon, to simultaneously remove sulfur and nitrogen [40] (Figure 4B). The system achieved $\mathrm{NH}_{4}{ }^{+}$removal efficiency as high as $96.4 \%$, along with $92.7 \%$ sulfide treatment (Table 3 ). With sacrificial iron anode as an electron donor, a biocathode-coupled electrocoagulation cell has been revealed to be able to support the biocathodic nitrification process [64] (Figure 4C). The results demonstrated that the $\mathrm{NH}_{4}{ }^{+}$removal rate reached 6.77-7.28 $\mathrm{mg} \mathrm{L}^{-1} \mathrm{~h}^{-1}$, accompanied with almost complete algae removal and a positive energy balance of $4.52-7.44 \mathrm{~W} \mathrm{~m}^{-3}$. The studies provided a new opportunity to remove nitrogen in the cathodic chamber along with the treatment of other contaminants than organic matter in the anodic chamber, although their results did not examine the complete removal of $\mathrm{NH}_{4}{ }^{+}$to $\mathrm{N}_{2}$, instead of stopping at the stage of nitrification. $\mathrm{NO}_{3}{ }^{-}$should be completely removed before the nitrogen contaminated wastewaters are discharged into natural environment. Therefore, further research should be carried out to evaluate the feasibility of such systems for complete conversion of $\mathrm{NH}_{4}{ }^{+}$to $\mathrm{N}_{2}$ through incorporating denitrification process. 

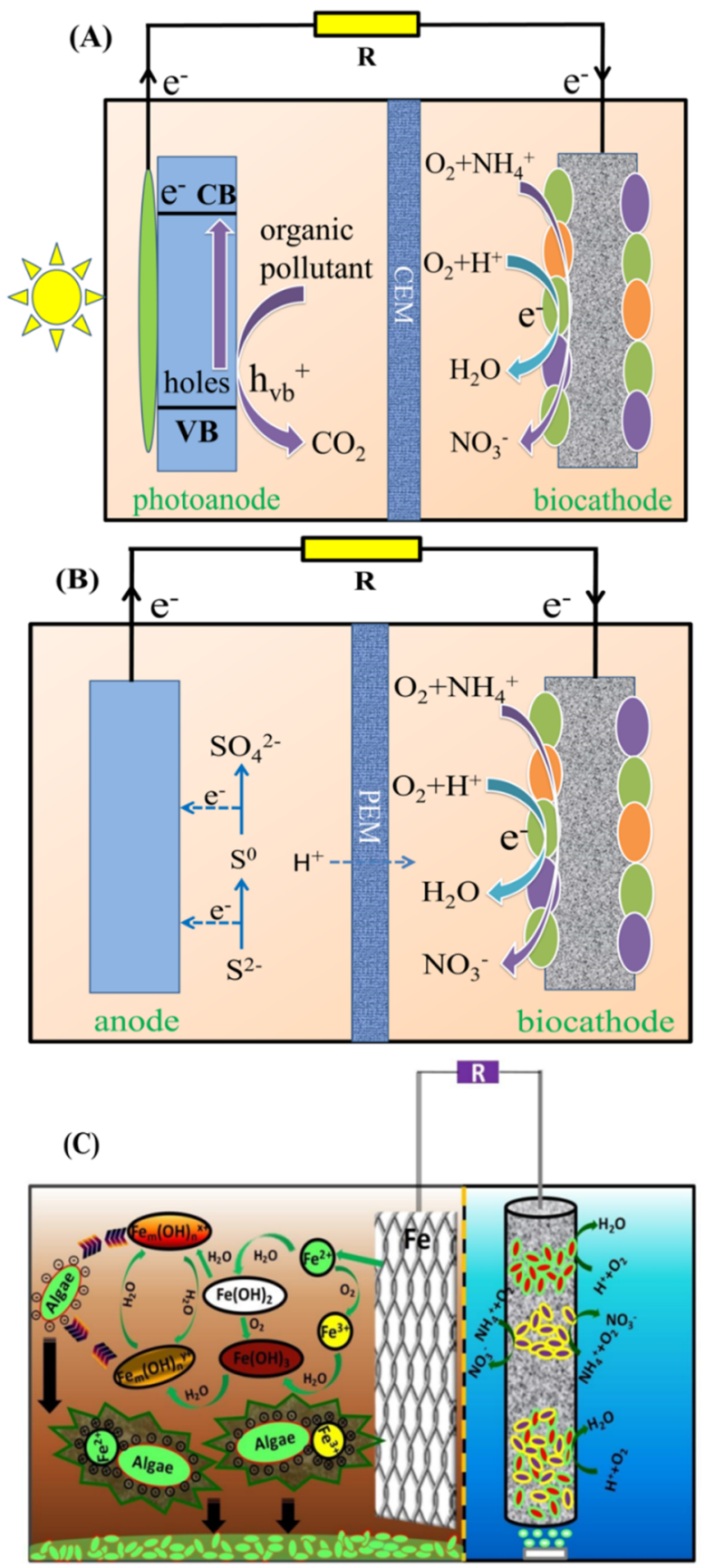

Figure 4. (A) Biocathode coupled photoelectrochemical cell, modified from [63]; (B) Schematic diagram of the MFC., modified from [40]; (C) Schematic diagrams of biocathode-coupled electrocoagulation cell (bio-ECC) and the reactions in the anode and cathode [64]. Reproduced with copyright, Elsevier.

\section{Structure of Cathode Biofilm}

The anode generates electrons from organic matter and flows into the cathode after flowing through the external circuit. Nitrate or nitrite reacts as corresponding electron receptors on the biofilm. The cathode electrode can directly transfer electrons to the active denitrifying bacteria to remove pollution.

Electroactive nitrogen removal biofilm has been accumulated through both pure and mixed culture. For pure species, the accumulated cathodic biofilm played a single role, such as nitrification, and denitrification, and then the contaminants were not completely converted to $\mathrm{N}_{2}$ [65]. Therefore, 
more attention has been given to inoculate biocathodic biofilm with mixed species to achieve the purpose of completel removal of $\mathrm{NH}_{4}{ }^{+}$, and $\mathrm{NO}_{3}{ }^{-}$as nitrogen gas. Functional microbes require different oxygen levels to carry out the nitrogen removal process, and thus mixed culture biofilm are stratified caused by the oxygen gradient [44]. It has been revealed that the aerobic outer biofilm layer was occupied by nitrifying microorganism, whereas the anaerobic inner layer was dominated by denitrifiers or anammox bacteria. Stratification of the cathodic biofilm achieved multiple nitrogen processes within one bioreactor, and thus was beneficial for the complete conversion of toxic nitrogen contaminants to nontoxic product of $\mathrm{N}_{2}$. To achieve ideal stratified biofilm, the DO concentration should be well controlled to obtain a reasonable ratio of aerobic and anaerobic biomass and avoid the accumulation of toxic intermediates such as $\mathrm{N}_{2} \mathrm{O}$. Furthermore, the thickness of the biofilm should be high enough to form an oxygen gradient from aerobic to anaerobic because a thin biofilm would be easily penetrated by dissolved oxygen.

Community structure analyses has been carried out to understand the composition of the functional biofilm, therefore, the relative abundance of microbes responsible for nitrogen removal could be revealed. It was observed that the relative abundance of functional genes demonstrated distinct difference along with the oxygen gradient within the cathodic biofilm. Denitrifiers such as Paracoccus and Pseudomonas spp. were more abundant within the inner biofilm, whereas B-proteobacterial AOB dominated the outer layers of the biofilm, because of the decreasing DO gradient from outer layer to inner layer of the biofilm [44]. Xiao et al. revealed that norB genes were more abundant within the inner layer of a heterotrophic denitrification biofilm carrying out bioelectrochemical removal of nitrate and inferred that $\mathrm{N}_{2} \mathrm{O}$ was mainly produced within the inner portion of the biofilm [66]. Meanwhile, the microbial structure also depended on the physical location in the cathodic chamber. In membrane-aerated BESs carrying out the nitritation-anammox process, on the one hand, AOB Nitrosomonadaceae accounted for $7.4 \%$ in the membrane biofilm, whereas it decreased to less than $1 \%$ in both cathode biofilm and suspended samples, because of the readily available oxygen on the surface of the aerated membrane for the growth of AOB [41]. On the other hand, anammox microbes of Candidatus Brocadiaceae dominated in the suspended samples with a relative abundance of $10.3 \%$, however, their relative abundance decreased to $\sim 0.5 \%$ in the membrane and cathode samples. Denitrifiers were the most abundant bacteria in the cathode biofilm, comprised of Comamonas, Paracoccus, Dechloromonas, Thermomonas, Rubrivivax, Simplicispira, Thiobacillus, and Geobacter responsible for alleviating nitrate accumulation. Additionally, the source of nitrogen was revealed to affect the microbial structure $[39,67]$. It was observed that $\mathrm{NO}_{2}{ }^{-}$, relative to $\mathrm{NO}_{3}{ }^{-}$, was the main screening for the microbial community of nitrogen removal biocathode [39]. Proteobacteria was the shared dominant phylum (40\%) in biofilms fed with $\mathrm{NO}_{3}{ }^{-}$, $\mathrm{NO}_{2}{ }^{-}$, or a mixture of $\mathrm{NO}_{3}{ }^{-}$and $\mathrm{NO}_{2}{ }^{-}$. However, Bacteroidetes was enriched within the biofilm fed with $\mathrm{NO}_{2}{ }^{-}$, probably because Bacteroidetes favor $\mathrm{NO}_{2}{ }^{-}$as an electron acceptor. Moreover, TM7 and Actinobacteria were enriched with $\mathrm{NO}_{3}{ }^{-}$as the sole electron acceptor, playing roles in nitrate removal. Oxygen was an electron acceptor that could be reduced by electroactive microbes [9]. Such oxygen reduction active microbes could accept electrons from the cathode and transfer the electrons to oxygen, instead of $\mathrm{NO}_{3}{ }^{-}$as the electron acceptor [25]. For instance, Zhao et al. observed that aerobic Truepera and Pelomonas accounted for 39.64\% within cathodic biofilm fed with $\mathrm{NO}_{2}^{-}$as the initial electron acceptor [52]. Their presence in nitrogen removal biofilm could compete for the electrons and oxygen, and thus could decrease the nitrogen removal capacity.

\section{Influencing Factors}

\subsection{Effects of Dissolved Oxygen}

Many factors can affect the nitrogen removal performance in BESs. They can be divided into two categories, that is, factors affecting the activity of nitrogen removal microbes and factors influencing the performance of electron generation and transfer. 
$\mathrm{DO}$ is a crucial factor to successfully carry out nitrogen removal processes. It should be well controlled because an excessive low DO concentration would result in incomplete nitrification, causing accumulation of $\mathrm{NH}_{4}{ }^{+}$, while a high DO could inhibit the activity of denitrifiers, leading to a decreased $\mathrm{NO}_{3}{ }^{-}$reduction rate [68]. It has been observed that a DO concentration of $4.35 \mathrm{mg} \mathrm{L}^{-1}$ was optimal, resulting in the highest nitrogen removal efficiency of $94.1 \%$ through BESs [22]. Increasing the DO concentration to $7.24 \mathrm{mg} \mathrm{L}^{-1}$, the $\mathrm{NH}_{4}{ }^{+}$concentration decreased, but led to $\mathrm{NO}_{3}{ }^{-}$accumulation and decreased the total nitrogen removal efficiency to $29.0 \%$. A similar optimal DO concentration of $4.4 \mathrm{mg} \mathrm{L}^{-1}$ was determined by Zhang et al. [69], at which concentration the highest total nitrogen removal efficiency was achieved. However, the optimal DO was determined as low as $0.5 \mathrm{mg} \mathrm{L}^{-1}$, accompanied with a nitrogen removal efficiency of $52 \%$ because of the enhanced denitrification process [70]. The different optimal DO concentrations could be caused by the different thicknesses of the cathodic biofilms, therefore, a different $\mathrm{DO}$ was required to achieve a suitable $\mathrm{DO}$ gradient to carry out the denitrification process. For aerobic cathodic biofilm, a biological oxidation-reduction reaction (ORR) would be unavoidable due to the similar reduction potential. A recent research observed that a simultaneous ORR benefitted the biological denitrification process because of the decreased oxygen concentration [71].

\subsection{Effects of $\mathrm{C} / \mathrm{N}$ Ratio}

The $\mathrm{C} / \mathrm{N}$ ratio is another factor that affects the removal efficiency of nitrogen contamination with a traditional bioprocess because organic carbon is required as an electron donor for heterotrophic denitrifiers [72]. Autotrophic denitrification requires a suitable $\mathrm{C} / \mathrm{N}$ ratio. When the $\mathrm{C} / \mathrm{N}$ ratio is from 2 to 2.7, the accumulation of nitrite is significantly reduced. A high $\mathrm{C} / \mathrm{N}$ ratio accelerates the growth of heterotrophic denitrifying bacteria in biofilms, resulting in more electrons, while a lower $\mathrm{C} / \mathrm{N}$ ratio facilitates the conversion of chemical energy into electrical energy. This indicates that a high $\mathrm{C} / \mathrm{N}$ ratio does not improve the autotrophic denitrification percentage in BESs, although it could improve the nitrogen removal effect. Increased $\mathrm{C} / \mathrm{N}$ ratios improved the ability of a BES to remove nitrate and depress nitrite accumulation but did not improve the autotrophic denitrification process. A high $\mathrm{C} / \mathrm{N}$ ratios postponed increased electrogenesis but did not improve the electric production efficiency at the anode. The autotrophic denitrification ratio decreased with an increasing $\mathrm{C} / \mathrm{N}$ ratio [73].

For a conventional biological process, the optimal $\mathrm{C} / \mathrm{N}$ ratio for aerobic denitrification has been determined to be about five, and sometimes 9 10 [74]. For a BES process, however, the cathode acts as an electron donor. Therefore, the $\mathrm{C} / \mathrm{N}$ ratio required for denitrification exists in a much broader range than that of a conventional biological process; especially, BESs can treat wastewaters with low a $\mathrm{C} / \mathrm{N}$ ratio [46]. Virdis et al. determined an optimal $\mathrm{C} / \mathrm{N}$ ratio of 3.02 accompanied with a total nitrogen removal efficiency of $77.7 \%$, which was slightly higher than $76.8 \%$ for a $\mathrm{C} / \mathrm{N}$ ratio of 1.88 [22]. Zhang et al. observed that the removal efficiency of both ammonium and nitrate was promoted with a decreased $\mathrm{C} / \mathrm{N}$ ratio from 8.43 to 2.81 [75]. In BESs with a high $\mathrm{C} / \mathrm{N}$ ratio, both heterotrophic and autotrophic bacteria coexist and together remove nitrogenous matters; whereas for wastewaters with a low $\mathrm{C} / \mathrm{N}$ ratio, autotrophic bacteria can be dominant and responsible for the removal of nitrogen compound with cathode as the electron donor [47], thereby treating objects with a low $\mathrm{C} / \mathrm{N}$ such as groundwater [26].

\subsection{Effects of $p H$}

The optimal $\mathrm{pH}$ for a conventional denitrification reaction is in the range of 7.0 8.0. During the denitrification process, however, the $\mathrm{pH}$ increases because of the formation of alkali [74]. Moreover, electrochemical active ORR microbes usually exist within the aerobic nitrogen-removal biofilm [52]. On the one hand, hydroxyl ions are released during the ORR process [76], which further intensifies the basicity of the catholyte of denitrification BESs. An unsuitable $\mathrm{pH}$ can inhibit the activity of enzymes related to nitrogen removal. On the other side, oxidation of $\mathrm{NH}_{4}{ }^{+}$releases protons [20]. Moreover, anodic degradation of organic matter also produces protons which can be transported 
to the cathodic chamber through ionic separator [77]. The protons are able to reduce the cathodic basicity to a lower $\mathrm{pH}$ to a certain extent, for example, from 8.8 to 7.05 [78], which is beneficial for the biological reduction of nitrogenous contaminants [20]. Clauwaert et al. observed that complete denitrification was achieved and the nitrogen removal rate doubled from 0.22 to $0.50 \mathrm{~kg} \mathrm{NO}_{3}{ }^{-} \mathrm{N} \mathrm{m}^{-3}$ net cathode chamber $\mathrm{d}^{-1}$ by controlling the catholyte $\mathrm{pH}$ at 7.2 [79]. However, the method was not cost-effective because of the consumption of chemicals to adjust the $\mathrm{pH}$. Through changing the poised potential of an electroactive biofilm, an ano-cathodophilic biofilm was established to oxidize organic matter and reduce nitrogen contaminants alternatively [80]. During the process, alkalinity, which resulted from cathodic denitrification, could partially (19\%) neutralize the anodic acidity caused by the degradation of organic matter. The catholyte $\mathrm{pH}$ could also be kept stable (e.g., 6.5 7.5) by looping the acidified anodic effluent as cathodic influent [81], eliminating the need for external chemicals to buffer the $\mathrm{pH}$.

\subsection{Effects of Hydraulic Retention Time}

HRT was also evaluated as a factor affecting the performance of nitrogen removal by BESs. It was found that shortening the HRT from $5.54 \mathrm{~h}$ to $2.27 \mathrm{~h}$ and increasing the temperature from $20{ }^{\circ} \mathrm{C}$ to $30^{\circ} \mathrm{C}$ favored both power generation and pollutant removal in an MFC where sulfide was removed in the anodic chamber and nitrate was reduced in the cathodic chamber [82]. The suitable HRT and temperature were determined as $2.27 \mathrm{~h}$ and $30^{\circ} \mathrm{C}$, at which a nitrate removal loading of $14.4 \pm 0.3 \mathrm{~g}-\mathrm{N} \mathrm{m}^{-3}$ net cathode chamber $\mathrm{d}^{-1}$ was achieved. Both the HRT and temperature were revealed as factors in the performance of MFCs, because the HRT affects the supply of substrate to the exoelectrogens, and the temperature influences the enzyme activity of microbes. At an optimal HRT and temperature, the anodic exoelectrogens work at the highest efficiency and more electrons are supplied to the electroactive denitrifiers, thus, achieving more efficient removal of nitrogen.

\subsection{Effects of External and Internal Resistance}

External and internal resistance could affect the electron flux from anode to the surface of cathode in BESs. Smaller external resistance could lead to larger electric current, and therefore, more electrons would be transported to the cathodic surface to support the reduction of nitrogenous contaminants, and thus promote nitrogen removal efficiency $[20,46,52]$. It has been observed that an external resistor of $10 \Omega$ resulted in rest nitrogen concentration under detectable limitation; however, only $38 \%$ of nitrogen was removed when the external resistance was increased to $1000 \Omega$ [83]. Yu et al. also revealed that the TN removal rate increased from 0.017 to $0.119 \mathrm{~kg} \mathrm{~m}^{-3} \mathrm{~d}^{-1}$ with a decreased external resistance from 1000 to $10 \Omega$ in a denitrification BES over nitrite [53]. Moreover, the decreased external resistance led to a reduced accumulation of $\mathrm{NO}_{3}{ }^{-}$, i.e., the concentration decreased from 88.73 to $26.97 \mathrm{mg} \mathrm{L}^{-1}$ when the external resistance decreased from 1000 to $10 \Omega$. The positive relationship between electron flow and nitrogen removal was further confirmed by controlling the electric current [84]. With an applied current of $5 \mathrm{~mA}$, the $\mathrm{NO}_{3}{ }^{-}$reduction rate was determined as $0.104 \pm 0.005 \mathrm{mM} \mathrm{N} \cdot \mathrm{h}^{-1}$ which was promoted to $0.225 \pm 0.004 \mathrm{mM} \mathrm{N} \cdot \mathrm{h}^{-1}$ with an applied current of $15 \mathrm{~mA}$. Variations in external resistance have been reported to change the electron transfer rate and alter the metabolic activity and substrate utilization kinetics of electroactive nitrogen reduction microbes [85]. A smaller resistance decreased the resistance of extracellular electron transfer and promoted the electron transfer rate, which promoted the nitrogen removal efficiency [86]. Moreover, decreasing the internal resistance was observed as an efficient way to promote the performance of BESs because a lower internal resistance was also a benefit to promote electron flux. A traditional method to decrease the internal resistance was carried out through addition of such chemicals as $\mathrm{NaCl}$ and buffer solution to increase the ionic strength [87-89]. A recent study observed that an addition of a sponge made of polyester polyurethane could decrease the solution resistance as well as cathodic charge resistance, and consequently promoted a nitrogen removal efficiency of $90.73 \%$ as compared with $68.85 \%$ of MFC without sponge addition [90]. 


\subsection{Effects of Cathodic Reactions}

Cathodic reactions have been considered to be limiting factors of the performance of BESs such as MFCs [91]. The property of cathode substrate such as material and surface area could affect the polarization behavior of the cathode, and further the electric current generation from BESs [49]. With better performance, larger current would be generated and more electrons would be provided for the bioelectrochemical reduction of nitrogenous contaminants. It has been observed that ammonia migration rate, and TN removal efficiency was promoted with increased cathode surface area, in a three-chamber MFCs with a middle chamber to contain $\mathrm{NH}_{4}{ }^{+}$wastewaters [69]. It has also been revealed that optimal spacing between the electrodes exited to achieve the largest $\mathrm{NH}_{4}{ }^{+}$migration rate and TN removal efficiency [69], because it was observed that the internal resistance of BESs was related to the distance between electrodes, further influencing the generation of electric current [92].

\subsection{Other Factors}

With respect to practical applications for treating real wastewaters, there could be other kinds of contaminants such as heavy metals and antibiotics other than nitrogenous pollutants. These co-exiting contaminants would negatively affect the function of both anodic and cathodic microbes, limiting the electron generation in the anode and further inhibiting the activity of heterotrophic and autotrophic nitrogen removal microbes on the cathode side. Chen et al. revealed that graphene oxide promoted the lactate dehydrogenase release, as well as the reactive oxygen species production, which further decreased the relative abundance of denitrification genes such as napA, nirS, and nirK over long-term operation of denitrification BESs [93]. The nitrate removal efficiency was reduced from $99.52 \%$ to $74.95 \%$ when the concentration of graphene oxide increased from 0 to $150 \mathrm{mg} / \mathrm{L}$. Similar inhibition effects and mechanism of vanadium have been revealed by a combined autotrophic denitrification process with sulfur and hydrogen as electron donors [94]. Consequently, the nitrate removal efficiency decreased from $98.06 \%$ at vanadium concentration of $0 \mathrm{mg} \mathrm{L}^{-1}$ to $52.16 \%$ at $100 \mathrm{mg} \mathrm{L}^{-1}$ vanadium.

\section{Conclusions}

As an important environmental contaminant, nitrogen can result in eutrophication and be harmful to the human body. Therefore, a great deal of attentions has been given to the development of a novel technology to remove nitrogen from the environment such as nitrogen gas. BESs have attracted much attention as a potential biological technology for reducing nitrogen concentration because of their unique advantages such as a broader $\mathrm{C} / \mathrm{N}$ ratio, as well as less energy consumption and sludge production. Prior studies have done a lot of work to evaluate combined nitrogen removal processes, reactor configurations, influencing factors, etc., as has been summarized in the present review. However, there are still several areas that need further investigation.

Electron flux is considered to be an important factor for nitrogen removal efficiency, especially for the autotrophic denitrification process with the aid of electroactive denitrifiers receiving electrons from the cathodic surface. Much attention has been given to promote the electron transfer rate from exoelectrogens to anodic surface or from the cathodic surface to exoelectrogens through chemical modification of the electrode surface. Moreover, many other methods have been examined to promote the performance of BESs in terms of electron production. These efficient methods could also be effective to promote nitrogen removal efficiency in BESs; however, there have been few reports on such methods to promote autotrophic nitrogen removal [95].

The electron transfer mechanism and kinetics between the biofilm/electrode interfaces were proven beneficial to regulate the efficiency of BESs [96]. The majority of attention, however, has been given to the biofilm/anode interface. The mechanism of electron transfer from cathode to biofilm has great significance for promoting the cathodic efficiency in terms of oxygen reduction and the removal of contaminants such as nitrogenous compound [97]. Therefore, more consideration is needed to reveal the electron transfer mechanism and factors of the electron transfer kinetics between the cathode 
and nitrogen removal biofilm, which would be beneficial for further promoting the removal efficiency of nitrogenous pollutants.

\section{Future Perspective}

Currently, one challenge facing BESs is the scaling up for practical application to treat real wastewaters in terms of optimization of the reactor configuration and operational parameters, long-term stability, investment, and operational costs. The operation of large-scale BESs for nitrogen removal is beneficial for discovering key factors of nitrogen removal efficiency and evaluating energy budget and economic benefits for practical applications of these biological systems.

Bioelectrochemical treatment of wastewater is usually an energy intensive process, and thus demonstrates significant potential for treating nitrogenous wastewaters relative to traditional biological processes. When treating actual wastewaters, operational costs have been given a great deal of attention. Therefore, adoption of BESs, independently or together with a traditional biological process could be an efficient pathway to reduce the total cost. Moreover, the operation of a BES could simultaneously treat organic matter contained wastewaters, which would further promote the potential of practical applications of BESs. Futhermore, the addition of a BES not only facilitates the removal of contaminants, but also avoids the addition of an additional electron donor in the cathode compartment, thus removing ammonia nitrogen at a low $\mathrm{C} / \mathrm{N}$ ratio, which demonstrates a significant advantage over traditional processes and expands the flexibility of a BES in practical applications. In summary, a BES has advantages for treating nitrogenous wastewaters over traditional processes and provides a novel method to remove nitrogenous matters from water environments.

Author Contributions: J.S. and H.C. collected the required materials and prepared the manuscript; Z.W. contributed the design and edition of the manuscript. All authors have read and agreed to the published version of the manuscript.

Funding: This research was funded by the project ZR2019MB070 supported by Shandong Provincial Natural Science Foundation.

Conflicts of Interest: The authors declare no conflict of interest.

\section{References}

1. Barnard, R.; Leadley, P.W.; Hungate, B.A. Global change, nitrification, and denitrification: A review. Glob. Biogeochem. Cycles 2005, 19. [CrossRef]

2. Sun, S.-P.; Nàcher, C.P.i.; Merkey, B.; Zhou, Q.; Xia, S.-Q.; Yang, D.-H.; Sun, J.-H.; Smets, B.F. Effective biological nitrogen removal treatment processes for domestic wastewaters with low $\mathrm{C} / \mathrm{N}$ ratios: A review. Environ. Eng. Sci. 2010, 27, 111-126. [CrossRef]

3. Bennetto, H.P.; Stirling, J.L.; Tanaka, K.; Vega, C.A. Anodic reactions in microbial fuel cells. Biotechnol. Bioeng. 1983, 25, 559-568. [CrossRef] [PubMed]

4. Pham, T.H.; Aelterman, P.; Verstraete, W. Bioanode performance in bioelectrochemical systems: Recent improvements and prospects. Trends Biotechnol. 2009, 27, 168-178. [CrossRef]

5. Wang, H.; Ren, Z.J. A comprehensive review of microbial electrochemical systems as a platform technology. Biotechnol. Adv. 2013, 31, 1796-1807. [CrossRef]

6. Kumar, R.; Singh, L.; Wahid, Z.A.; Din, M.F.M. Exoelectrogens in microbial fuel cells toward bioelectricity generation: A review. Int. J. Energy Res. 2015, 39, 1048-1067. [CrossRef]

7. Pant, D.; Van Bogaert, G.; Diels, L.; Vanbroekhoven, K. A review of the substrates used in microbial fuel cells (MFCs) for sustainable energy production. Bioresour. Technol. 2010, 101, 1533-1543. [CrossRef]

8. Ucar, D.; Zhang, Y.; Angelidaki, I. An Overview of Electron Acceptors in Microbial Fuel Cells. Front. Microbiol. 2017, 8, 643. [CrossRef] [PubMed]

9. Wang, Z.; Zheng, Y.; Xiao, Y.; Wu, S.; Wu, Y.; Yang, Z.; Zhao, F. Analysis of oxygen reduction and microbial community of air-diffusion biocathode in microbial fuel cells. Bioresour. Technol. 2013, 144, 74-79. [CrossRef]

10. Virdis, B.; Rabaey, K.; Yuan, Z.; Keller, J. Microbial fuel cells for simultaneous carbon and nitrogen removal. Water Res. 2008, 42, 3013-3024. [CrossRef] 
11. Zhou, J.; Gao, J.; Liu, Y.; Xiao, S.; Zhang, R.; Zhang, Z. Contaminant removal performances on domestic sewage using modified anoxic/anaerobic/oxic process and micro-electrolysis. Environ. Technol. 2013, 34, 2773-2779. [CrossRef] [PubMed]

12. Kelly, P.T.; He, Z. Nutrients removal and recovery in bioelectrochemical systems: A review. Bioresour. Technol. 2014, 153, 351-360. [CrossRef]

13. Clauwaert, P.; Rabaey, K.; Aelterman, P.; De Schamphelaire, L.; Pham, T.H.; Boeckx, P.; Boon, N.; Verstraete, W. Biological denitrification in microbial fuel cells. Environ. Sci. Technol. 2007, 41, 3354-3360. [CrossRef] [PubMed]

14. Puig, S.; Coma, M.; Desloover, J.; Boon, N.; Colprim, J.; Balaguer, M.D. Autotrophic Denitrification in Microbial Fuel Cells Treating Low Ionic Strength Waters. Environ. Sci. Technol. 2012, 46, 2309-2315. [CrossRef]

15. Chang, C.-N.; Cheng, H.-B.; Chao, A.C. Applying the Nernst equation to simulate redox potential variations for biological nitrification and denitrification processes. Environ. Sci. Technol. 2004, 38, 1807-1812. [CrossRef] [PubMed]

16. Nguyen, V.K.; Hong, S.; Park, Y.; Jo, K.; Lee, T. Autotrophic denitrification performance and bacterial community at biocathodes of bioelectrochemical systems with either abiotic or biotic anodes. J. Biosci. Bioeng. 2015, 119, 180-187. [CrossRef] [PubMed]

17. Yang, N.; Zhan, G.; Li, D.; Wang, X.; He, X.; Liu, H. Complete nitrogen removal and electricity production in Thauera-dominated air-cathode single chambered microbial fuel cell. Chem. Eng. J. 2019, 356, 506-515. [CrossRef]

18. Park, H.I.; Kim, D.k.; Choi, Y.-J.; Pak, D. Nitrate reduction using an electrode as direct electron donor in a biofilm-electrode reactor. Process Biochem. 2005, 40, 3383-3388. [CrossRef]

19. Peng, Y.; Zhu, G. Biological nitrogen removal with nitrification and denitrification via nitrite pathway. Appl. Microbiol. Biotechnol. 2006, 73, 15-26. [CrossRef]

20. Zhang, F.; He, Z. Simultaneous nitrification and denitrification with electricity generation in dual-cathode microbial fuel cells. J. Chem. Technol. Biotechnol. 2012, 87, 153-159. [CrossRef]

21. Zhang, F.; Ge, Z.; Grimaud, J.; Hurst, J.; He, Z. Long-Term Performance of Liter-Scale Microbial Fuel Cells Treating Primary Effluent Installed in a Municipal Wastewater Treatment Facility. Environ. Sci. Technol. 2013, 47, 4941-4948. [CrossRef]

22. Virdis, B.; Rabaey, K.; Rozendal, R.A.; Yuan, Z.; Keller, J. Simultaneous nitrification, denitrification and carbon removal in microbial fuel cells. Water Res. 2010, 44, 2970-2980. [CrossRef]

23. Liang, Y.; Feng, H. Removal and Recovery of Nitrogen Pollutants in Bioelectrochemical System. In Bioelectrochemistry Stimulated Environmental Remediation; Springer: Singapore, 2019; pp. 157-203.

24. Liu, H.; Yan, Q.; Shen, W. Biohydrogen facilitated denitrification at biocathode in bioelectrochemical system (BES). Bioresour. Technol. 2014, 171, 187-192. [CrossRef] [PubMed]

25. Zhao, J.; Wu, J.; Li, X.; Wang, S.; Hu, B.; Ding, X. The Denitrification Characteristics and Microbial Community in the Cathode of an MFC with Aerobic Denitrification at High Temperatures. Front. Microbiol. 2017, 8, 9. [CrossRef] [PubMed]

26. Molognoni, D.; Devecseri, M.; Cecconet, D.; Capodaglio, A.G. Cathodic groundwater denitrification with a bioelectrochemical system. J. Water Process Eng. 2017, 19, 67-73. [CrossRef]

27. Zhao, Y.; Feng, C.; Wang, Q.; Yang, Y.; Zhang, Z.; Sugiura, N. Nitrate removal from groundwater by cooperating heterotrophic with autotrophic denitrification in a biofilm-electrode reactor. J. Hazard. Mater. 2011, 192, 1033-1039. [CrossRef]

28. Arredondo, M.R.; Kuntke, P.; Jeremiasse, A.; Sleutels, T.; Buisman, C.; Ter Heijne, A. Bioelectrochemical systems for nitrogen removal and recovery from wastewater. Environ. Sci. Water Res. Technol. 2015, 1, $22-33$. [CrossRef]

29. Ding, W.; Cheng, S.; Yu, L.; Huang, H. Effective swine wastewater treatment by combining microbial fuel cells with flocculation. Chemosphere 2017, 182, 567-573. [CrossRef] [PubMed]

30. Lang, X.; Li, Q.; Ji, M.; Yan, G.; Guo, S. Isolation and niche characteristics in simultaneous nitrification and denitrification application of an aerobic denitrifier, Acinetobacter sp. YS2. Bioresour. Technol. 2020, 302, 122799. [CrossRef] [PubMed]

31. Wang, X.; Ma, Y.; Peng, Y.; Wang, S. Short-cut nitrification of domestic wastewater in a pilot-scale A/O nitrogen removal plant. Bioprocess Biosyst. Eng. 2007, 30, 91-97. [CrossRef] 
32. Ma, B.; Zhang, S.; Zhang, L.; Yi, P.; Wang, J.; Wang, S.; Peng, Y. The feasibility of using a two-stage autotrophic nitrogen removal process to treat sewage. Bioresour. Technol. 2011, 102, 8331-8334. [CrossRef] [PubMed]

33. Chen, T.; Zheng, P.; Tang, C.; Wang, S.; Ding, S. Performance of ANAMMOX-EGSB reactor. Desalination 2011, 278, 281-287. [CrossRef]

34. Yan, H.; Saito, T.; Regan, J.M. Nitrogen removal in a single-chamber microbial fuel cell with nitrifying biofilm enriched at the air cathode. Water Res. 2012, 46, 2215-2224. [CrossRef] [PubMed]

35. Wu, D.; Yi, X.; Tang, R.; Feng, C.; Wei, C. Single microbial fuel cell reactor for coking wastewater treatment: Simultaneous carbon and nitrogen removal with zero alkaline consumption. Sci. Total Environ. 2018, 621, 497-506. [CrossRef] [PubMed]

36. Zhang, G.; Shi, Y.; Zhang, H.; Yang, F.; Cai, L. Operation adjustments of an electrochemically coupled system for total nitrogen removal and the associated mechanism. Chemosphere 2020, 246, 125649. [CrossRef] [PubMed]

37. Sevda, S.; Sreekrishnan, T.R. Removal of organic matters and nitrogenous pollutants simultaneously from two different wastewaters using biocathode microbial fuel cell. J. Environ. Sci. Health Part A Toxic/Hazard. Subst. Environ. Eng. 2014, 49, 1265-1275. [CrossRef] [PubMed]

38. Pei, H.; Yang, Z.; Nie, C.; Hou, Q.; Zhang, L.; Wang, Y.; Zhang, S. Using a tubular photosynthetic microbial fuel cell to treat anaerobically digested effluent from kitchen waste: Mechanisms of organics and ammonium removal. Bioresour. Technol. 2018, 256, 11-16. [CrossRef]

39. Zhang, Y.; Xu, W.; Xiang, Y.; Xie, B.; Liu, H.; Wu, L.; Liang, D. Kinetics and gene diversity of denitrifying biocathode in biological electrochemical systems. RSC Adv. 2017, 7, 24981-24987. [CrossRef]

40. Bao, R.; Zhang, S.; Zhao, L.; Zhong, L. Simultaneous sulfide removal, nitrification, and electricity generation in a microbial fuel cell equipped with an oxic cathode. Environ. Sci. Pollut. Res. Int. 2017, 24, 5326-5334. [CrossRef]

41. Yang, Y.; Li, X.; Yang, X.; He, Z. Enhanced nitrogen removal by membrane-aerated nitritation-anammox in a bioelectrochemical system. Bioresour. Technol. 2017, 238, 22-29. [CrossRef]

42. Al-Mamun, A.; Jafary, T.; Baawain, M.S.; Rahman, S.; Choudhury, M.R.; Tabatabaei, M.; Lam, S.S. Energy recovery and carbon/nitrogen removal from sewage and contaminated groundwater in a coupled hydrolytic-acidogenic sequencing batch reactor and denitrifying biocathode microbial fuel cell. Environ. Res. 2020, 183. [CrossRef]

43. Zhou, Y.H.; Zhao, S.M.; Yin, L.; Zhang, J.; Bao, Y.; Shi, H.X. Development of a Novel Membrane-less Microbial Fuel Cell (ML-MFC) with a Sandwiched Nitrifying Chamber for Efficient Wastewater Treatment. Electroanalysis 2018, 30, 2145-2152. [CrossRef]

44. Virdis, B.; Read, S.T.; Rabaey, K.; Rozendal, R.A.; Yuan, Z.; Keller, J. Biofilm stratification during simultaneous nitrification and denitrification (SND) at a biocathode. Bioresour. Technol. 2011, 102, 334-341. [CrossRef]

45. Zhang, G.; Zhang, H.; Ma, Y.; Yuan, G.; Yang, F.; Zhang, R. Membrane filtration biocathode microbial fuel cell for nitrogen removal and electricity generation. Enzym. Microb. Technol. 2014, 60, 56-63. [CrossRef] [PubMed]

46. Wu, Y.; Yang, Q.; Zeng, Q.; Ngo, H.H.; Guo, W.; Zhang, H. Enhanced low C/N nitrogen removal in an innovative microbial fuel cell (MFC) with electroconductivity aerated membrane (EAM) as biocathode. Chem. Eng. J. 2017, 316, 315-322. [CrossRef]

47. Li, H.; Zuo, W.; Tian, Y.; Zhang, J.; Di, S.; Li, L.; Su, X. Simultaneous nitrification and denitrification in a novel membrane bioelectrochemical reactor with low membrane fouling tendency. Environ. Sci. Pollut. Res. Int. 2017, 24, 5106-5117. [CrossRef] [PubMed]

48. Li, Y.; Williams, I.; Xu, Z.; Li, B.; Li, B. Energy-positive nitrogen removal using the integrated short-cut nitrification and autotrophic denitrification microbial fuel cells (MFCs). Appl. Energy 2016, 163, 352-360. [CrossRef]

49. Wang, Z.; Mahadevan, G.D.; Wu, Y.; Zhao, F. Progress of air-breathing cathode in microbial fuel cells. J. Power Sources 2017, 356, 245-255. [CrossRef]

50. Ruiz, G.; Jeison, D.; Chamy, R. Nitrification with high nitrite accumulation for the treatment of wastewater with high ammonia concentration. Water Res. 2003, 37, 1371-1377. [CrossRef]

51. Puig, S.; Serra, M.; Vilar-Sanz, A.; Cabre, M.; Baneras, L.; Colprim, J.; Balaguer, M.D. Autotrophic nitrite removal in the cathode of microbial fuel cells. Bioresour. Technol. 2011, 102, 4462-4467. [CrossRef] [PubMed] 
52. Zhao, H.; Zhao, J.; Li, F.; Li, X. Performance of Denitrifying Microbial Fuel Cell with Biocathode over Nitrite. Front. Microbiol. 2016, 7, 344. [CrossRef] [PubMed]

53. Yu, Y.; Zhao, J.; Wang, S.; Zhao, H.; Ding, X.; Gao, K. Nitrogen removal and electricity production at a double-chamber microbial fuel cell with cathode nitrite denitrification. Environ. Technol. 2017, 38, 3093-3101. [CrossRef] [PubMed]

54. Li, W.; Zhang, S.; Chen, G.; Hua, Y. Simultaneous electricity generation and pollutant removal in microbial fuel cell with denitrifying biocathode over nitrite. Appl. Energy 2014, 126, 136-141. [CrossRef]

55. Gregory, K.B.; Bond, D.R.; Lovley, D.R. Graphite electrodes as electron donors for anaerobic respiration. Environ. Microbiol. 2004, 6, 596-604. [CrossRef] [PubMed]

56. Fux, C.; Boehler, M.; Huber, P.; Brunner, I.; Siegrist, H. Biological treatment of ammonium-rich wastewater by partial nitritation and subsequent anaerobic ammonium oxidation (anammox) in a pilot plant. J. Biotechnol. 2002, 99, 295-306. [CrossRef]

57. Tsushima, I.; Kindaichi, T.; Okabe, S. Quantification of anaerobic ammonium-oxidizing bacteria in enrichment cultures by real-time PCR. Water Res. 2007, 41, 785-794. [CrossRef]

58. Jin, R.-C.; Ma, C.; Yu, J.-J. Performance of an Anammox UASB reactor at high load and low ambient temperature. Chem. Eng. J. 2013, 232, 17-25. [CrossRef]

59. Li, C.; Ren, H.; Xu, M.; Cao, J. Study on anaerobic ammonium oxidation process coupled with denitrification microbial fuel cells (MFCs) and its microbial community analysis. Bioresour. Technol. 2015, 175, 545-552. [CrossRef]

60. Wu, S.; Lv, T.; Lu, Q.; Ajmal, Z.; Dong, R. Treatment of anaerobic digestate supernatant in microbial fuel cell coupled constructed wetlands: Evaluation of nitrogen removal, electricity generation, and bacterial community response. Sci. Total Environ. 2017, 580, 339-346. [CrossRef]

61. Zhang, H.; Ge, C.; Yu, M.; Zhang, J.; Wang, Y.; Cai, L.; Yang, F. Performance of cathodic nitrate reduction driven by electricity generated from ANAMMOX sludge in anode. Process Biochem. 2020, 90, 148-155. [CrossRef]

62. Lim, S.J.; Park, W.; Kim, T.-H.; Shin, I.H. Swine wastewater treatment using a unique sequence of ion exchange membranes and bioelectrochemical system. Bioresour. Technol. 2012, 118, 163-169. [CrossRef] [PubMed]

63. Du, Y.; Feng, Y.; Qu, Y.; Liu, J.; Ren, N.; Liu, H. Electricity generation and pollutant degradation using a novel biocathode coupled photoelectrochemical cell. Environ. Sci. Technol. 2014, 48, 7634-7641. [CrossRef] [PubMed]

64. Dong, Y.; Qu, Y.; Li, C.; Han, X.; Ambuchi, J.J.; Liu, J.; Yu, Y.; Feng, Y. Simultaneous algae-polluted water treatment and electricity generation using a biocathode-coupled electrocoagulation cell (bio-ECC). J. Hazard. Mater. 2017, 340, 104-112. [CrossRef] [PubMed]

65. Yu, L.; Yuan, Y.; Chen, S.; Zhuang, L.; Zhou, S. Direct uptake of electrode electrons for autotrophic denitrification by Thiobacillus denitrificans. Electrochem. Commun. 2015, 60, 126-130. [CrossRef]

66. Xiao, Y.; Wu, S.; Yang, Z.H.; Wang, Z.J.; Yan, C.Z.; Zhao, F. In situ probing the effect of potentials on the microenvironment of heterotrophic denitrification biofilm with microelectrodes. Chemosphere 2013, 93, 1295-1300. [CrossRef]

67. Kondaveeti, S.; Lee, S.H.; Park, H.D.; Min, B. Bacterial communities in a bioelectrochemical denitrification system: The effects of supplemental electron acceptors. Water Res. 2014, 51, 25-36. [CrossRef]

68. Daigger, G.T. Oxygen and carbon requirements for biological nitrogen removal processes accomplishing nitrification, nitritation, and anammox. Water Environ. Res. A Res. Publ. Water Environ. Fed. 2014, 86, $204-209$. [CrossRef]

69. Zhang, X.; Zhu, F.; Chen, L.; Zhao, Q.; Tao, G. Removal of ammonia nitrogen from wastewater using an aerobic cathode microbial fuel cell. Bioresour. Technol. 2013, 146, 161-168. [CrossRef]

70. Yu, C.P.; Liang, Z.; Das, A.; Hu, Z. Nitrogen removal from wastewater using membrane aerated microbial fuel cell techniques. Water Res. 2011, 45, 1157-1164. [CrossRef]

71. Jiang, X.; Ying, D.; Ye, D.; Zhang, R.; Guo, Q.; Wang, Y.; Jia, J. Electrochemical study of enhanced nitrate removal in wastewater treatment using biofilm electrode. Bioresour. Technol. 2018, 252, 134-142. [CrossRef]

72. Miao, Y.; Peng, Y.; Zhang, L.; Li, B.; Li, X.; Wu, L.; Wang, S. Partial nitrification-anammox (PNA) treating sewage with intermittent aeration mode: Effect of influent $\mathrm{C} / \mathrm{N}$ ratios. Chem. Eng. J. 2018, 334, 664-672. [CrossRef] 
73. Huang, B.; Feng, H.; Wang, M.; Li, N.; Cong, Y.; Shen, D. The effect of C/N ratio on nitrogen removal in a bioelectrochemical system. Bioresour. Technol. 2013, 132, 91-98. [CrossRef] [PubMed]

74. Ji, B.; Yang, K.; Zhu, L.; Jiang, Y.; Wang, H.; Zhou, J.; Zhang, H. Aerobic denitrification: A review of important advances of the last 30 years. Biotechnol. Bioprocess Eng. 2015, 20, 643-651. [CrossRef]

75. Zhang, F.; He, Z. Integrated organic and nitrogen removal with electricity generation in a tubular dual-cathode microbial fuel cell. Process Biochem. 2012, 47, 2146-2151. [CrossRef]

76. Wang, Z.; Cao, C.; Zheng, Y.; Chen, S.; Zhao, F. Abiotic Oxygen Reduction Reaction Catalysts Used in Microbial Fuel Cells. ChemElectroChem 2014, 1, 1813-1821. [CrossRef]

77. Zhang, L.; Li, J.; Zhu, X.; Ye, D.-d.; Liao, Q. Effect of proton transfer on the performance of unbuffered tubular microbial fuel cells in continuous flow mode. Int. J. Hydrog. Energy 2015, 40, 3953-3960. [CrossRef]

78. You, S.J.; Ren, N.Q.; Zhao, Q.L.; Kiely, P.D.; Wang, J.Y.; Yang, F.L.; Fu, L.; Peng, L. Improving phosphate buffer-free cathode performance of microbial fuel cell based on biological nitrification. Biosens. Bioelectron. 2009, 24, 3698-3701. [CrossRef]

79. Clauwaert, P.; Desloover, J.; Shea, C.; Nerenberg, R.; Boon, N.; Verstraete, W. Enhanced nitrogen removal in bio-electrochemical systems by $\mathrm{pH}$ control. Biotechnol. Lett. 2009, 31, 1537-1543. [CrossRef]

80. Cheng, K.Y.; Ginige, M.P.; Kaksonen, A.H. Ano-cathodophilic biofilm catalyzes both anodic carbon oxidation and cathodic denitrification. Environ. Sci. Technol. 2012, 46, 10372-10378. [CrossRef]

81. Xie, S.; Liang, P.; Chen, Y.; Xia, X.; Huang, X. Simultaneous carbon and nitrogen removal using an oxic/anoxic-biocathode microbial fuel cells coupled system. Bioresour. Technol. 2011, 102, 348-354. [CrossRef]

82. Zhong, L.; Zhang, S.; Wei, Y.; Bao, R. Power recovery coupled with sulfide and nitrate removal in separate chambers using a microbial fuel cell. Biochem. Eng. J. 2017, 124, 6-12. [CrossRef]

83. Jia, Y.H.; Tran, H.T.; Kim, D.H.; Oh, S.J.; Park, D.H.; Zhang, R.H.; Ahn, D.H. Simultaneous organics removal and bio-electrochemical denitrification in microbial fuel cells. Bioprocess Biosyst. Eng. 2008, 31, 315-321. [CrossRef] [PubMed]

84. Virdis, B.; Rabaey, K.; Yuan, Z.; Rozendal, R.A.; Keller, J.r. Electron fluxes in a microbial fuel cell performing carbon and nitrogen removal. Environ. Sci. Technol. 2009, 43, 5144-5149. [CrossRef]

85. Zhang, L.; Zhu, X.; Li, J.; Liao, Q.; Ye, D. Biofilm formation and electricity generation of a microbial fuel cell started up under different external resistances. J. Power Sources 2011, 196, 6029-6035. [CrossRef]

86. Katuri, K.P.; Scott, K.; Head, I.M.; Picioreanu, C.; Curtis, T.P. Microbial fuel cells meet with external resistance. Bioresour. Technol. 2011, 102, 2758-2766. [CrossRef]

87. Ye, Y.; Zhu, X.; Logan, B.E. Effect of buffer charge on performance of air-cathodes used in microbial fuel cells. Electrochim. Acta 2016, 194, 441-447. [CrossRef]

88. Ahn, Y.; Logan, B.E. Saline catholytes as alternatives to phosphate buffers in microbial fuel cells. Bioresour. Technol. 2013, 132, 436-439. [CrossRef]

89. Forrestal, C.; Huang, Z.; Ren, Z.J. Percarbonate as a naturally buffering catholyte for microbial fuel cells. Bioresour. Technol. 2014, 172, 429-432. [CrossRef]

90. Deng, L.; Ngo, H.-H.; Guo, W.; Wang, J.; Zhang, H. Evaluation of a new sponge addition-microbial fuel cell system for removing nutrient from low C/N ratio wastewater. Chem. Eng. J. 2018, 338, 166-175. [CrossRef]

91. Rismani-Yazdi, H.; Carver, S.M.; Christy, A.D.; Tuovinen, O.H. Cathodic limitations in microbial fuel cells: An overview. J. Power Sources 2008, 180, 683-694. [CrossRef]

92. Cheng, S.; Liu, H.; Logan, B.E. Increased power generation in a continuous flow MFC with advective flow through the porous anode and reduced electrode spacing. Environ. Sci. Technol. 2006, 40, 2426-2432. [CrossRef]

93. Chen, D.; Wang, X.; Yang, K.; Wang, H. Response of a three dimensional bioelectrochemical denitrification system to the long-term presence of graphene oxide. Bioresour. Technol. 2016, 214, 24-29. [CrossRef] [PubMed]

94. Chen, D.; Xiao, Z.; Wang, H.; Yang, K. Toxic effects of vanadium (V) on a combined autotrophic denitrification system using sulfur and hydrogen as electron donors. Bioresour. Technol. 2018, 264, 319-326. [CrossRef] [PubMed]

95. Choi, T.S.; Song, Y.C.; Joicy, A. Influence of conductive material on the bioelectrochemical removal of organic matter and nitrogen from low strength wastewater. Bioresour. Technol. 2018, 259, 407-413. [CrossRef] [PubMed] 
96. Kumar, R.; Singh, L.; Zularisam, A.W. Exoelectrogens: Recent advances in molecular drivers involved in extracellular electron transfer and strategies used to improve it for microbial fuel cell applications. Renew. Sustain. Energy Rev. 2016, 56, 1322-1336. [CrossRef]

97. Huang, L.; Regan, J.M.; Quan, X. Electron transfer mechanisms, new applications, and performance of biocathode microbial fuel cells. Bioresour. Technol. 2011, 102, 316-323. [CrossRef] [PubMed]

(C) 2020 by the authors. Licensee MDPI, Basel, Switzerland. This article is an open access article distributed under the terms and conditions of the Creative Commons Attribution (CC BY) license (http://creativecommons.org/licenses/by/4.0/). 